\title{
Catalytic Oxidation of Methylene Blue by Use of Natural Zeolite-Based Silver and Magnetite Nanocomposites
}

\author{
Aldiyar Kuntubek ${ }^{1,2}$, Nurassyl Kinayat ${ }^{1,2}$, Kulyash Meiramkulova ${ }^{3}$, Stavros G. Poulopoulos ${ }^{1,2}$, \\ Joseph C. Bear ${ }^{4, *}$ and Vassilis J. Inglezakis ${ }^{1,2, * \mathbb{D}}$ \\ 1 Environmental Science \& Technology Group (ESTg), Department of Chemical \& Materials Engineering, \\ School of Engineering \& Digital Sciences, Nazarbayev University, Nur-Sultan 020000, Kazakhstan; \\ aldiyar.kuntubek@nu.edu.kz (A.K.); nurassyl.kinayat@nu.edu.kz (N.K.); \\ stavros.poulopoulos@nu.edu.kz (S.G.P.) \\ 2 The Environment \& Resource Efficiency Cluster (EREC), Nazarbayev University, \\ Nur-Sultan 010000, Kazakhstan \\ 3 Department of Environmental Engineering \& Management, L.N.Gumilyov Eurasian National University, \\ Nur-Sultan 02000, Kazakhstan; kuleke@gmail.com \\ 4 School of Life Science, Pharmacy \& Chemistry, Kingston University, Penrhyn Road, London KT1 2EE, UK \\ * Correspondence: J.Bear@kingston.ac.uk (J.C.B.); vasileios.inglezakis@nu.edu.kz (V.J.I.)
}

Received: 21 January 2020; Accepted: 27 February 2020; Published: 16 April 2020

\begin{abstract}
This work reports the synthesis of natural zeolite-based silver and magnetite nanocomposites and their application for the catalytic oxidation of methylene blue in water. The zeolite was impregnated with $5.5 \mathrm{wt} . \%$ Fe in the form of magnetite nanoparticles with size of $32 \mathrm{~nm}$, and with $6.4 \mathrm{wt} . \% \mathrm{Ag}$ in the form of silver oxide and metallic silver nanoparticles with sizes of 42 and $20 \mathrm{~nm}$, respectively. The results showed that physical adsorption contributed to the removal of methylene blue by $25-36 \%$ and that $\mathrm{Fe}_{3} \mathrm{O}_{4} @ \mathrm{NZU}$ is superior to $\mathrm{Ag}_{2} \mathrm{O} @ \mathrm{NZU}$ and $\mathrm{Ag}^{0} @ \mathrm{NZU}$, leading to $55 \%$ removal without oxidant and $97 \%$ in the presence of $\mathrm{H}_{2} \mathrm{O}_{2}$. However, there is no evidence of significant mineralization of methylene blue. The application of reaction rate models showed that the reaction order changes from zero to first and second order depending on the $\mathrm{H}_{2} \mathrm{O}_{2}$ concentration.
\end{abstract}

Keywords: zeolites; clinoptilolite; methylene blue; oxidation; nanoparticles; silver; silver oxide; magnetite

\section{Introduction}

Pollution of water with organic dyes is a major concern due to their harmful effects to the environment and human health [1-4]. Textile, leather, paper and other industries use dyes to color their products and consequently waste significant amounts of water. This results in polluted and colored wastewater that requires treatment [5]. An estimation shows that there are more than 100,000 commercial dyes available on the market with over $7 \times 10^{5}$ tons dye produced per year [6-8]. Unusual color of the water is the first sign of contaminated water with dyes; even 1 ppm of some dyes can be easily recognized without sophisticated equipment $[9,10]$.

Methylene blue (MB) or methylthioninium chloride is an organic thiazine-class cationic dye commonly used in the cotton, pharmaceuticals, wood and textile industry. The structure of MB is shown in Figure 1. As far as toxicity to humans is concerned, acute levels of intravenous exposure to MB can lead to hypertension, sweating, chest pain, confusion, nausea, vomiting, dizziness, and cyanosis, as well as to urine and stool discoloration [11]. Other health effects after exposure to MB can be carcinoma of the bladder [12], tissue necrosis [13], spinal cord necrosis [14], paraplegia [11], infancy 
problems [15-19], membrane rupture [20], and reproductive effects [21]. Finally, MB is a severe eye irritant $[11,22]$ and high concentrations might lead to corneal and conjunctival injury and other ocular disorders [23].

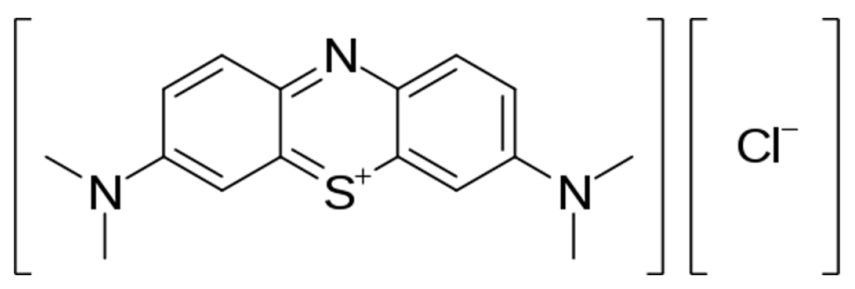

Figure 1. The molecular structure of MB.

Physical adsorption and catalytic oxidation are the most common processes for MB removal from water. Hydrogen peroxide in combination with catalysts, $\mathrm{UV}$ or visible light is frequently used as an oxidant in degradation of many toxic and harmful organic compounds, including dyes in wastewater, due to its high efficiency and relative low toxicity as it decomposes into water and oxygen gas [24]. Recently, natural and synthetic zeolites modified with metal ions have attracted attention as effective catalysts in oxidation reactions of dyes such as MB by hydrogen peroxide. Zeolites are promising catalysts due to their low cost, stability, high surface area and ion exchange capacity $[25,26]$. Zeolites are a group of aluminosilicates, which contain open tetrahedral framework, allowing ion exchange and reversible dehydration [27]. The spaces between adjacent polyhedral cavities are of suitable size to let neutral molecules and/or cations to travel through the crystal from one cavity into another [28]. The aforementioned spaces can form channels allowing large guest species to be exchanged. The tetrahedra in the framework are connected by twofold coordinated oxygen atoms creating strong bonds that form the framework itself [29]. Also, the affinity of zeolites towards guest ions and molecules depend on the $\mathrm{Si} / \mathrm{Al}$ ratio and differences in this ratio result in variations in several properties such as the distribution of negative charge density in the zeolitic framework, pores of different diameters and amount and location of extra framework cations. The affinity of zeolites towards guest molecules is also strongly dependent on the $\mathrm{Si} / \mathrm{Al}$ ratio. Consequently, useful properties, such as uniform pores, exchange and enclosure of active metal species, make zeolites convenient and effective in catalytic processes [30]. Furthermore, zeolites can be synthesized on an industrial scale along with aluminosilicate hydrogels, which can be prepared from various precipitated silicas, aluminum salts, blast furnace slag and many other compounds, or clay minerals are used as a raw material [31]. The properties of zeolites are especially useful for Fenton-like reactions, which constitute a common method for MB degradation. For instance, $4 \AA$ zeolite-supported zero valence iron nanoparticles (nZVI/4A) was studied by Wu et al. [25]. The authors highlighted the effect of $\mathrm{pH}$ on the oxidative activity in Fenton-like reactions, showing that the catalyst promoted oxidation by $\mathrm{OH}$ radicals at low $\mathrm{pH}$. The efficiency for $\mathrm{MB}$ removal ranged from $70 \%$ to $100 \%$, favored by low $\mathrm{pH}$ at 2-3 and depends on the medium and the dosage of the catalyst. Lopes et al. studied different zeolites as catalysts for $\mathrm{MB}$ decolorization and used numerous transitional metals to modify them. For instance, $\mathrm{NaY}$ and $\mathrm{Na} \beta$ zeolites were modified into $\mathrm{Y}-\mathrm{Fe}$ and $\mathrm{Y}-\mathrm{Cu}, \beta-\mathrm{Fe}$ and $\beta$ - $\mathrm{Cu}$, respectively [32]. The main finding was that despite the fact that the surface area was higher for Y-Fe and Y-Cu than for $\beta-\mathrm{Fe}$ and $\beta-\mathrm{Cu}$, the cavity size being microporous for the former prevented the diffusion of $\mathrm{MB}$ molecules within the pores, which lowered the efficiency of the oxidation, whereas the cavity size for the latter, being mesoporous, enhanced the catalytic oxidation. Consequently, the Y-Cu and Y-Fe did not achieve significant oxidation of $\mathrm{MB}$, showcasing adsorption rather than oxidation as the main mechanism for the dye removal. The efficiency for MB oxidation by the $\beta-\mathrm{Cu}$ and the $\beta$-Fe was $80 \%$ and $90 \%$, respectively. 
Table 1 summarizes the published papers on MB oxidation by use of metal-doped zeolites. The zeolites used in the oxidation of $\mathrm{MB}$ are of both synthetic and natural and the most used oxidant is $\mathrm{H}_{2} \mathrm{O}_{2}$. As is evident, there are several gaps in the literature that can be summarized as follows:

- The studies on zeolitic nanocomposites are few

- Magnetite zeolitic nanocomposites have not been studied

- A direct comparison of different nanocomposites in a single study is missing

- In most of studies the mineralization of MB via total carbon measurements is not studied

- The effect of the $\mathrm{H}_{2} \mathrm{O}_{2}$ concentration on the reaction order is rarely presented

Table 1. Metals-doped zeolites used for the oxidation of the MB.

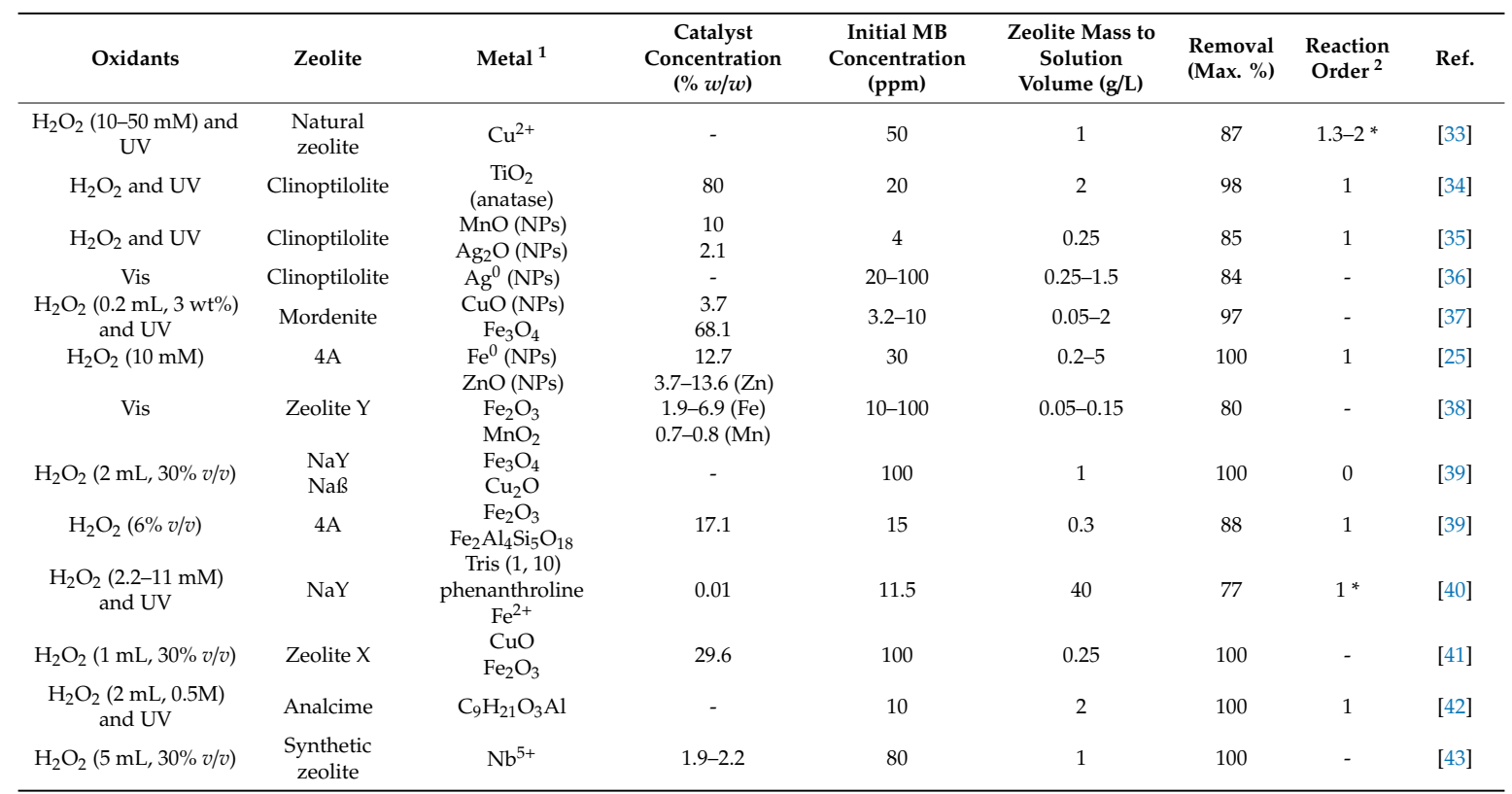

${ }^{1}$ The notation (NPs) in this table is used only for studies where the formation of nanoparticles is confirmed by XRD and/or TEM. ${ }^{2}$ The notation $\left({ }^{*}\right)$ is used for cases where the effect of the $\mathrm{H}_{2} \mathrm{O}_{2}$ concentration on the reaction order was studied.

The present work comes to address these gaps by presenting the synthesis of three forms of clinoptilolite-based nanocomposite catalysts, namely $\mathrm{Ag}^{0}, \mathrm{Ag}_{2} \mathrm{O}$ and $\mathrm{Fe}_{3} \mathrm{O}_{4}$ and their catalytic activity towards discoloration of $\mathrm{MB}$ solutions. The study includes total carbon measurements and kinetics modeling for studying the effect of $\mathrm{H}_{2} \mathrm{O}_{2}$ concentration on the reaction order.

\section{Materials and Methods}

\subsection{Materials}

The natural zeolite was purchased from Transcarpathian Zeolitic Factory (Khust District, Ukraine) and after washing and sieving the 800-1400 $\mu \mathrm{m}$ fraction was used. $\mathrm{AgNO}_{3}, \mathrm{NaCl}, \mathrm{NaBH}_{4}, \mathrm{FeSO}_{4} \cdot 7 \mathrm{H}_{2} \mathrm{O}$ and $\mathrm{FeCl}_{3}$ anhydrous (all ACS reagent grade) purchased from Sigma Aldrich (St. Louis, MO, USA) were used for zeolite modification. For the preparation of all solutions deionized water (DI) was used obtained from Millipore (Burlington, MA, USA) equipment equipped with a reverse osmosis module.

\subsection{Characterization Equipment}

X-ray Fluorescence (XRF) analysis was performed on XRF Axios Max (PANalytical, Malvern, UK) equipped with standard analysis software (Omnian, Malvern, UK). X-ray Diffraction was performed on an XRD system (Shimadzu, Kyoto, Japan) equipped with a $\mathrm{CuK} \alpha$ radiation source $(0.1549 \mathrm{~nm})$ over 
the $2 \theta$ range from $5^{\circ}$ to $90^{\circ}$. X-ray photoelectron spectroscopy (XPS) spectra were recorded using a K-alpha instrument (Thermo Scientific Ltd., Waltham, MA, USA). All spectra were collected using an Al-K $\alpha$ radiation $(1486.6 \mathrm{eV})$, monochromatized by a twin crystal monochromator, yielding focused an elliptical X-ray spot with a major axis length of $400 \mu \mathrm{m}$ at $3 \mathrm{~mA} \times 12 \mathrm{kV}$. SEM/EDS measurements were carried out by scanning electron microscopy (SEM) using a Crossbeam 540 device (ZEISS, Oberkochen, Germany) operating in LV mode at $15 \mathrm{kV}$ equipped with a backscattered electron detector was used for morphological characterization. Transmission Electron Microscopy (TEM) images were captured by a JEM 1400 Plus instrument (JEOL, Tokyo, Japan). The porous structure was studied using low temperature nitrogen adsorption measured on AutoSorb iQ (Quantachrome Instruments, Boynton Beach, FL, USA).

\subsection{Modification of Zeolites}

\subsubsection{Modification with Sodium Chloride (NZU-Na)}

Natural zeolite (NZU, $100 \mathrm{~g}$ ) was mixed with $2 \mathrm{~L}$ of $1 \mathrm{M} \mathrm{NaCl}$ solution under stirring and heating at $60^{\circ} \mathrm{C}$. The solution was replaced every day for 7 days. Following modification, the samples were washed with DI water until chloride ions were not detected after adding $\mathrm{AgNO}_{3}$ to the solution. Samples were then dried in the oven at $60^{\circ} \mathrm{C}$ for $8 \mathrm{~h}$ and placed in a desiccator.

\subsubsection{Modification with Silver Oxide $\left(\mathrm{Ag}_{2} \mathrm{O} @ \mathrm{NZU}\right)$}

NZU-Na (10 g) was mixed with $600 \mathrm{~mL}$ of $0.1 \mathrm{M} \mathrm{AgNO}_{3}$ solution in dark conditions for $48 \mathrm{~h}$. Samples were then washed with DI water 3-5 times and dried in an oven for $8 \mathrm{~h}$ at $60{ }^{\circ} \mathrm{C}$ and placed in a desiccator.

\subsubsection{Modification with Silver Nanoparticles $\left(\mathrm{Ag}^{0} @ \mathrm{NZU}\right)$}

NZU-Na (13.5 g) was mixed with $135 \mathrm{~mL}$ of $0.01 \mathrm{M} \mathrm{AgNO}_{3}$ solution in dark conditions for $24 \mathrm{~h}$. The procedure was repeated with fresh $\mathrm{AgNO}_{3}$ solution and then the samples were washed with DI water and dried in an oven at $100^{\circ} \mathrm{C}$ for $3 \mathrm{~h}$. The samples were placed in a beaker kept in a tank with ice and mixed with $0.05 \mathrm{M} \mathrm{NaBH}_{4}$ under dark conditions for $1 \mathrm{~h}$. Following the reduction step the samples were washed with DI water several times until $\mathrm{pH} 7$ dried at $100^{\circ} \mathrm{C}$ in an oven overnight and stored in a desiccator.

\subsubsection{Modification with Magnetite $\left(\mathrm{Fe}_{3} \mathrm{O}_{4} @ \mathrm{NZU}\right)$}

A $400 \mathrm{~mL}$ solution of $0.02 \mathrm{M} \mathrm{FeSO}_{4} \cdot 7 \mathrm{H}_{2} \mathrm{O}$ and $0.04 \mathrm{M}$ of $\mathrm{FeCl}_{3}$ was prepared with DI water under continuous intensive stirring on a heating plate at $80^{\circ} \mathrm{C}$. After $30 \mathrm{~min}$ of $1 \mathrm{M} \mathrm{NaOH}$ was added dropwise at a rate of $1 \mathrm{drop} / \mathrm{sec}$ until $\mathrm{pH}$ 12. Then the solution was left for an hour on a hot plate, after which the precipitate was removed by centrifugation at $3500 \mathrm{rpm}$. The sample was washed several times, dried in an oven at $105^{\circ} \mathrm{C}$ for $8 \mathrm{~h}$ and stored in a desiccator.

\subsection{Kinetic Measurements of Dye Discoloration}

MB solution ( $500 \mathrm{~mL}, 50 \mathrm{ppm}$ ) was prepared with DI water. $0.5 \mathrm{~g}$ of catalyst were added to a $100 \mathrm{~mL}$ solution containing 25 ppm MB and $42.4 \mathrm{mM}$ or $212 \mathrm{mM} \mathrm{H}_{2} \mathrm{O}_{2}$. The $\mathrm{H}_{2} \mathrm{O}_{2}$ added corresponds to 10 and 50 times the stoichiometric concentration for complete oxidation of $\mathrm{MB}$ to carbon dioxide. The $\mathrm{pH}$ of the solutions was 6.3 and remained the same after $24 \mathrm{~h}$ of contact with the solids. Two control experiments were used, namely (a) NZU in the absence of $\mathrm{H}_{2} \mathrm{O}_{2}$ and (b) all reagents without solids. The MB concentration in the solution was measured by a PhotoLab 6600 UV-Vis spectrophotometer (WTW, White Plains, NY, USA) at 660-668 nm and total carbon by a Multi N/Cb 3100 (Analytik Jena, Jena, Germany). 


\section{Results \& Discussion}

\subsection{Porosimetry}

Porosimetry results are shown in Figures 2 and 3. The surface area of NZU is $12.6 \mathrm{~m}^{2} / \mathrm{g}$, the pore volume $0.03 \mathrm{~cm}^{3} / \mathrm{g}$ and the average pore diameter $5.8 \mathrm{~nm}$. The adsorption-desorption isotherms with the hysteresis branch are characteristic of microporous-mesoporous zeolites such as clinoptilolite [44]. Also, the modification of samples had no significant impact on the surface area, pore volume and pore diameter.

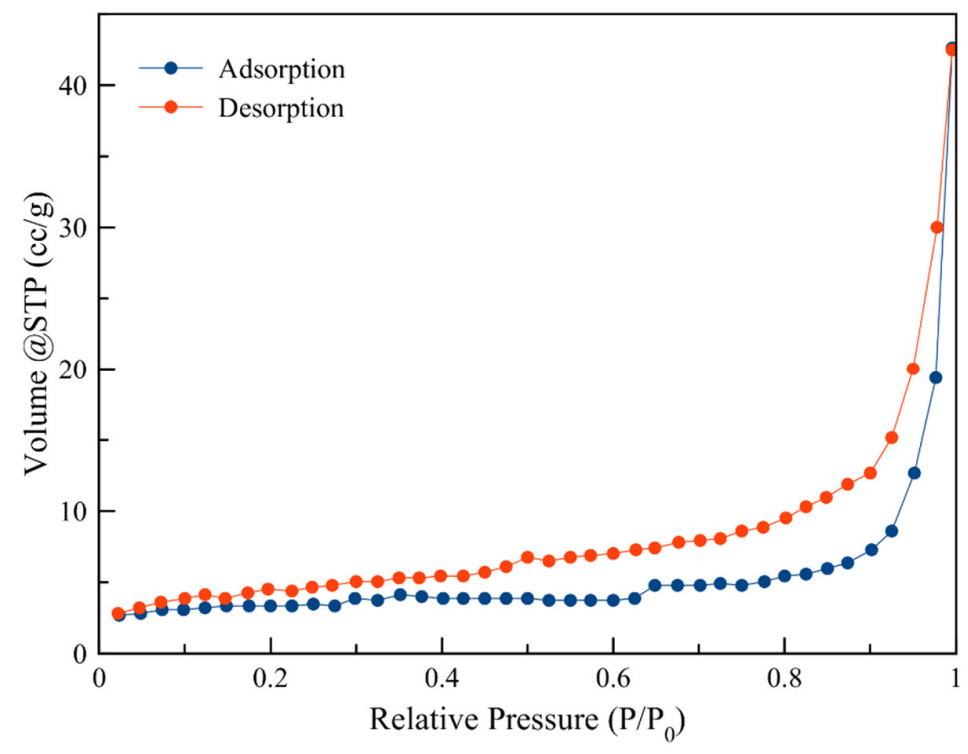

Figure 2. Adsorption-desorption isotherms of NZU.
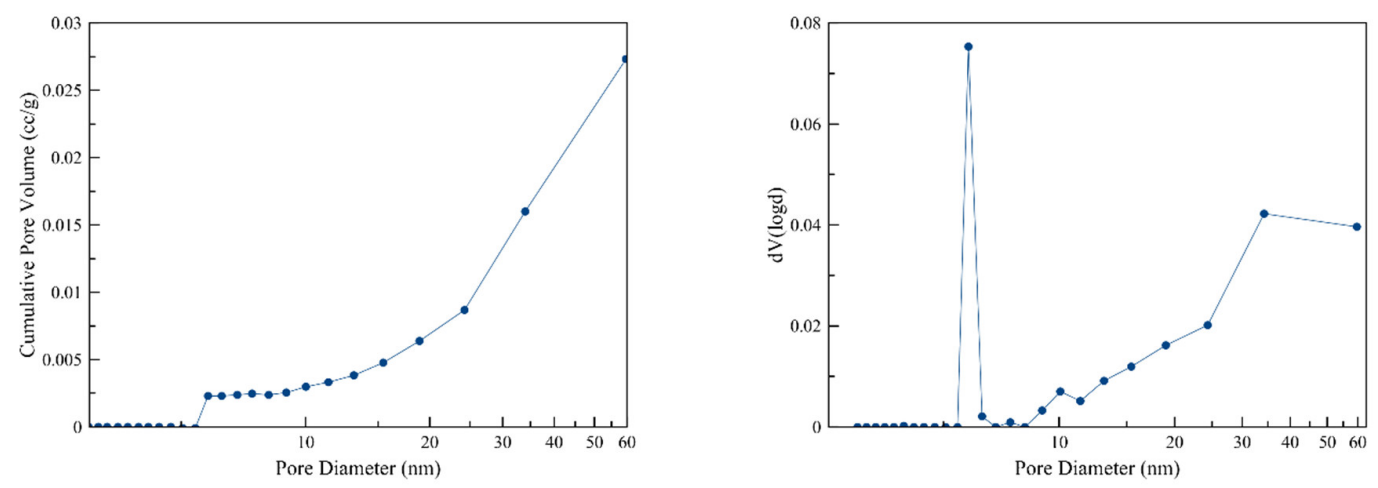

Figure 3. Cumulative pore volume (left) and pore size distribution of NZU (right).

\subsection{X-ray Fluorescence (XRF)}

The XRF chemical analysis results are shown in Table 2. Ag and Fe content is similar in the synthesized samples with Ag samples retaining a significant amount of Fe which comes from NZU and may act as catalyst. 
Table 2. X-ray Fluorescence (XRF) results in wt\%.

\begin{tabular}{ccccc}
\hline Sample & $\mathbf{A l}_{\mathbf{2}} \mathbf{O}_{\mathbf{3}}$ & $\mathbf{S i O}_{\mathbf{2}}$ & $\mathbf{F e}_{\mathbf{2}} \mathbf{O}_{\mathbf{3}}$ & $\mathbf{A g}_{\mathbf{2}} \mathbf{O}$ \\
\hline $\mathrm{NZU}$ & 12.9 & 77.3 & 1.6 & 0 \\
$\mathrm{NZU-Na}$ & 12.7 & 78.5 & 1.5 & 0 \\
$\mathrm{Fe}_{3} \mathrm{O}_{4} @ \mathrm{NZU}$ & 9.5 & 75.6 & 7.9 & 0 \\
$\mathrm{Ag}_{2} \mathrm{O} @ \mathrm{NZU}$ & 11.7 & 72.8 & 1.5 & 6.9 \\
$\mathrm{Ag}^{0} @ \mathrm{NZU}$ & 11.6 & 69.9 & 1.4 & 6.8 \\
\hline
\end{tabular}

\subsection{X-ray Diffraction (XRD)}

From the XRD patterns in Figure 4, it can be seen that the zeolite is clinoptilolite with peaks at $2 \theta$ of $9.93,17.23,22.43,29.87,50.04$.

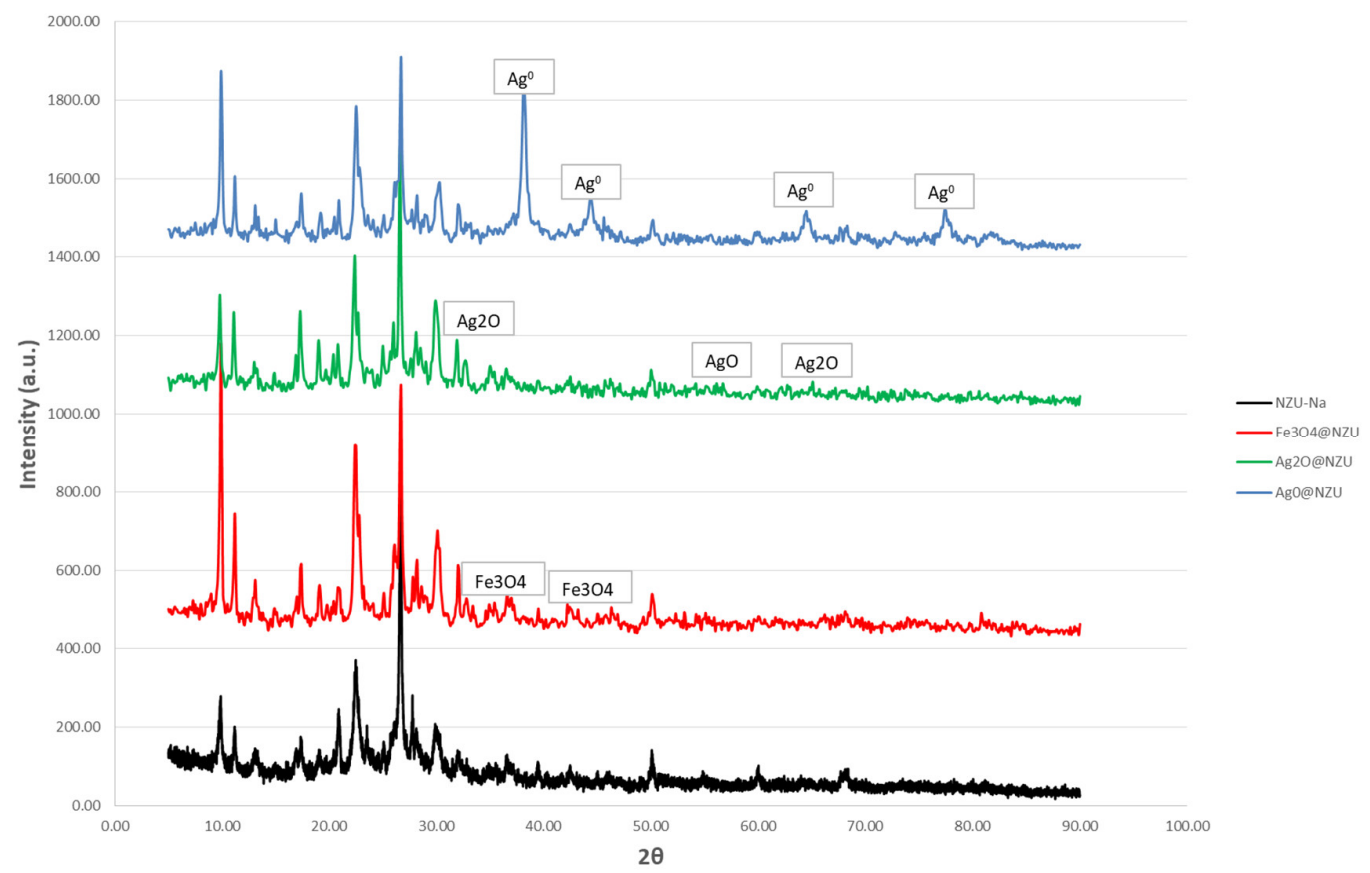

Figure 4. XRD spectra of $\mathrm{NZU}, \mathrm{Fe}_{3} \mathrm{O}_{4} @ \mathrm{NZU}, \mathrm{Ag}_{2} \mathrm{O} @ \mathrm{NZU}$ and $\mathrm{Ag}^{0} @ \mathrm{NZU}$ samples.

Based on the material certificate provided by the manufacturer the purity is $80 \%$. The peaks at $2 \theta$ of $35.48^{\circ}$ and $43.25^{\circ}$ in the $\mathrm{Fe}_{3} \mathrm{O}_{4} @ \mathrm{NZU}$ sample are attributed to magnetite, at $2 \theta$ of $56.70^{\circ}$ and $32.68^{\circ}$, $65.05^{\circ}$ in the $\mathrm{Ag}_{2} \mathrm{O} @ \mathrm{NZU}$ sample to $\mathrm{AgO}$ and $\mathrm{Ag}_{2} \mathrm{O}$, respectively and at $2 \theta$ of $38.16^{\circ}, 44.30^{\circ}, 64.47^{\circ}$ and $77.40^{\circ}$ in the $\mathrm{Ag}^{0} @ \mathrm{NZU}$ sample to $\mathrm{Ag}^{0}$. The approximate NPs size calculated based on the Schrerrer's formula is $32 \mathrm{~nm}$ for $\mathrm{Fe}_{3} \mathrm{O}_{4}, 42 \mathrm{~nm}$ for $\mathrm{Ag}_{2} \mathrm{O}$ and $20 \mathrm{~nm}$ for $\mathrm{Ag}^{0}$.

\subsection{X-ray Photoelectron Spectroscopy (XPS)}

XPS was done only for the Na-NZU in order to obtain the oxidation forms of the Fe contained in the parent zeolite as it can affect the redox reactions. The results showed that Na-NZU contains both $\mathrm{Fe}^{2+}$ and $\mathrm{Fe}^{3+}$ (III) species which are catalytic active with approximate content of $68.3 \%$ and $31.7 \%$, respectively. The pale green color of the $\mathrm{Na}-\mathrm{NZU}$ is in agreement with the predominance of $\mathrm{Fe}^{2+}$ species. Figure 5 shows a high resolution scan in the Fe2p region, with two iron environments which agrees with oxidized iron as given in the NIST XPS database. Fe2p Scan A is recorded at $711.58 \mathrm{eV}$ and Scan B at $714.38 \mathrm{eV}$, commensurate with $\mathrm{Fe}^{2+}$ in magnetite [45] and an $\mathrm{Fe}^{3+}$ species, most likely the $\mathrm{Fe}_{2} \mathrm{O}_{3}$ component of an $\mathrm{Fe}_{3} \mathrm{O}_{4} / \mathrm{Fe}_{2} \mathrm{O}_{3}$ mixture respectively. Finally, the survey scan shown in the ESI supports the elemental composition as analysed by EDS spectroscopy, showing the presence of oxygen, carbon, magnesium, iron, sodium, aluminium and silicon (Figure 6). 


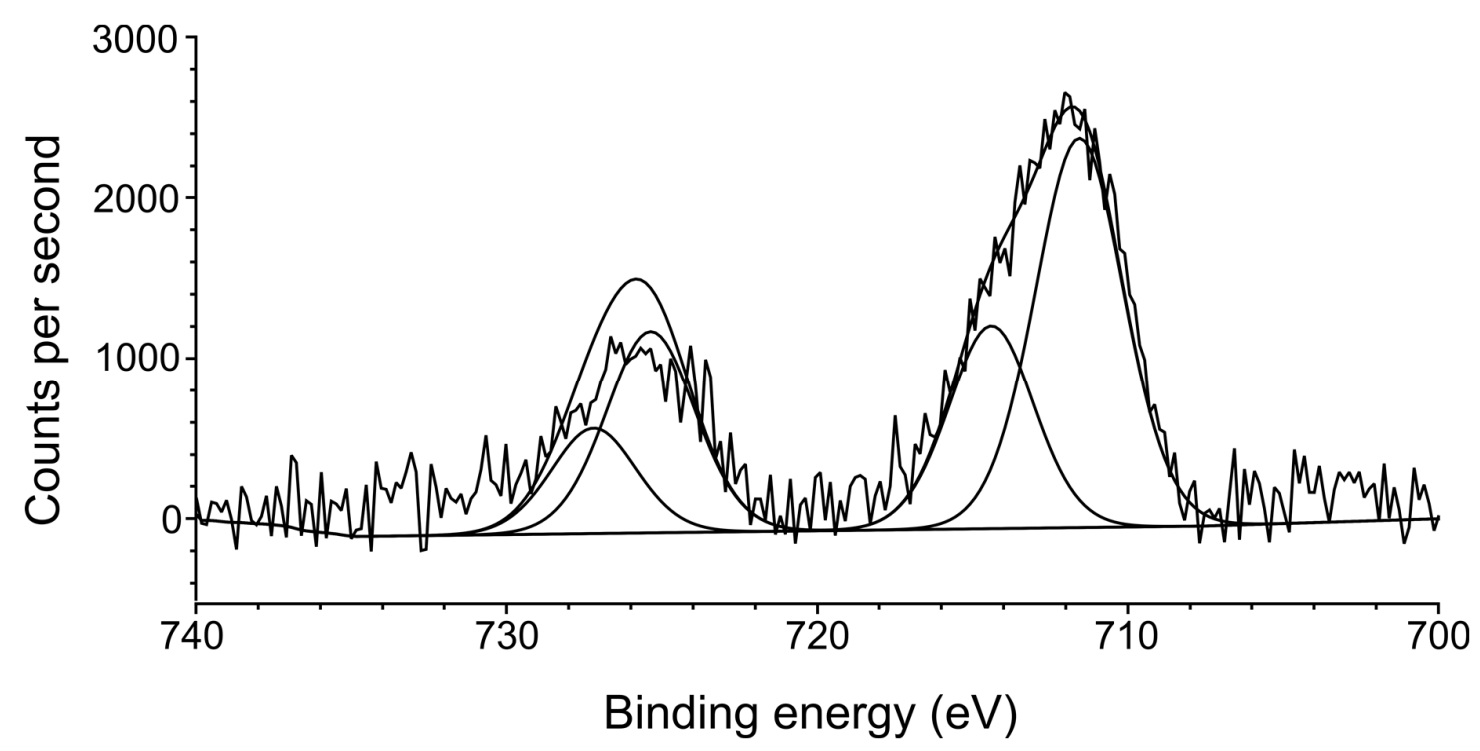

Figure 5. X-ray photoelectron spectroscopy of Na-NZU. Doublet separation was $13.50 \mathrm{eV}$.

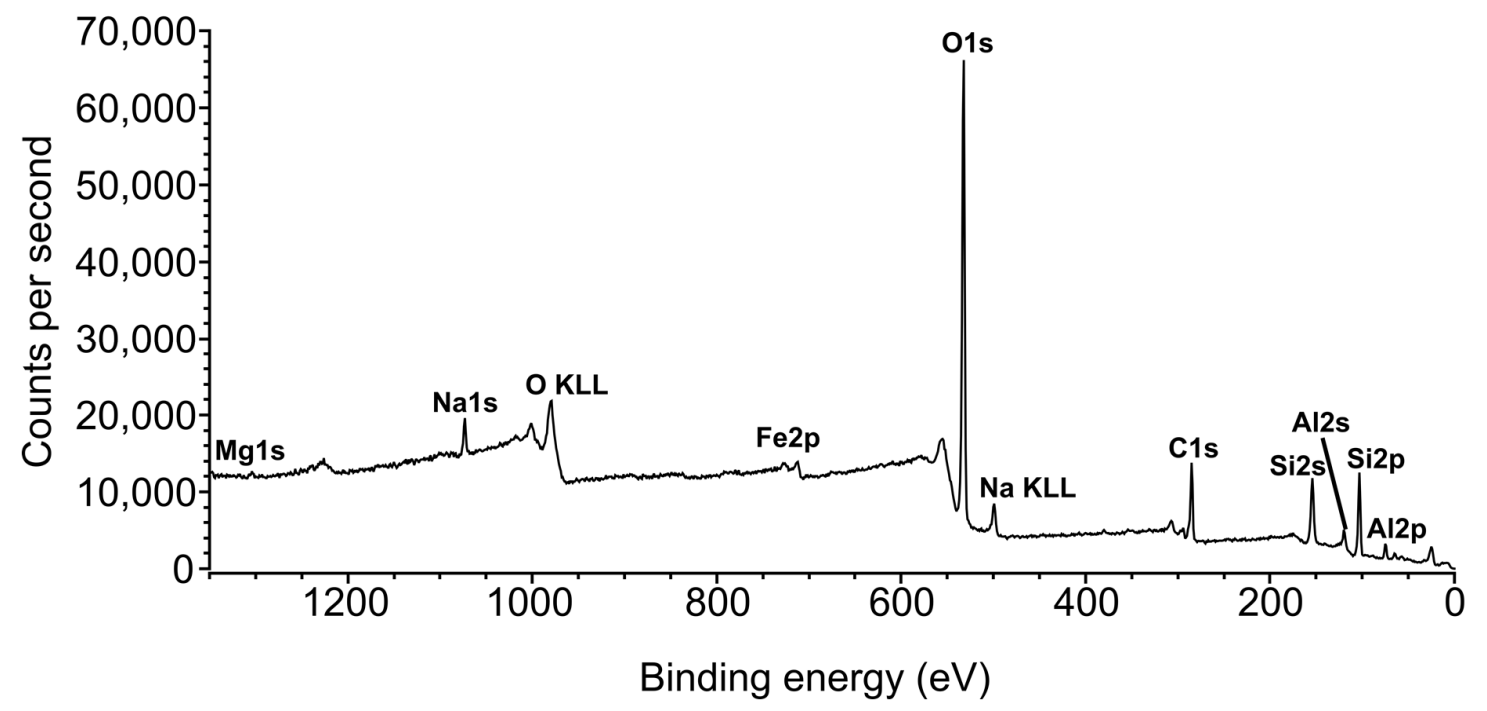

Figure 6. XPS survey scan of the Na-NZU zeolite over the range $0-1350 \mathrm{eV}$.

3.5. Scanning Electron Microscopy (SEM) and Energy Dispersive X-ray (EDS) Spectroscopy Measurements

Figure 7 shows the SEM images of the samples. SEM images demonstrate that there are no changes on the morphology of the zeolite surface. The EDS show metals uniformly distributed on the zeolite surface. There is no change after the adsorption and reaction with MB. 


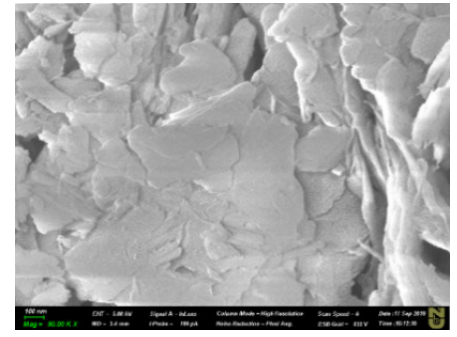

(A)

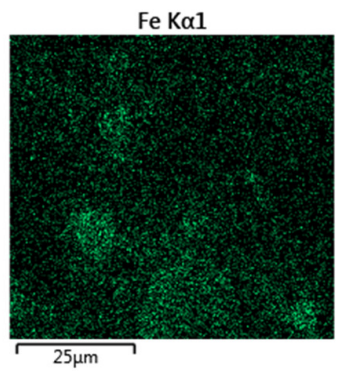

(D)

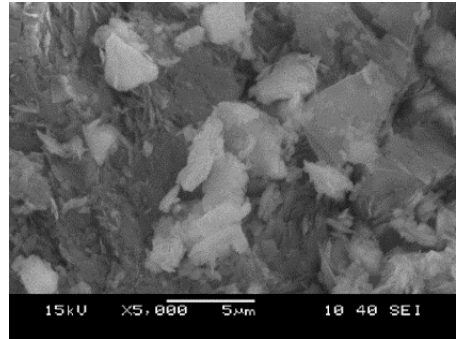

(B)

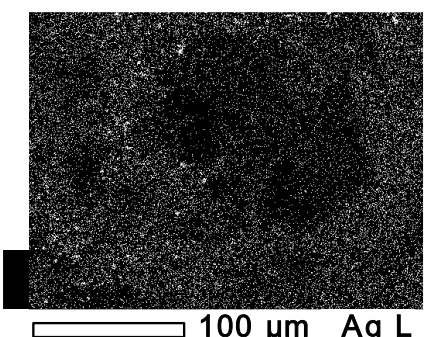

(E)

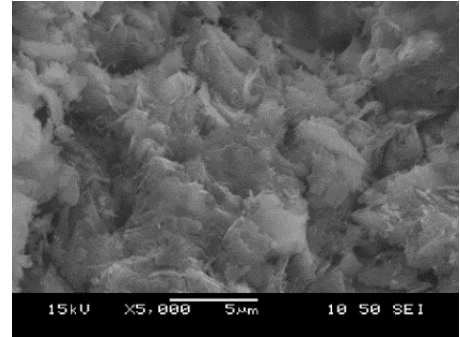

(C)

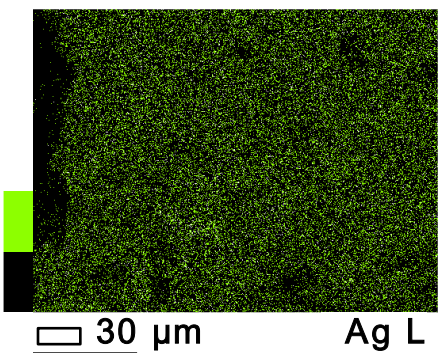

(F)

Figure 7. Scanning electron microscopy images of (A) $\mathrm{Fe}_{3} \mathrm{O}_{4} @ \mathrm{NZU},(\mathbf{B}) \mathrm{Ag}_{2} \mathrm{O} @ \mathrm{NZU},(\mathbf{C}) \mathrm{Ag}^{0} @ \mathrm{NZU}$ and energy dispersive X-ray spectroscopy of (D) iron on $\mathrm{Fe}_{3} \mathrm{O}_{4} @ \mathrm{NZU}$ and silver on (E) $\mathrm{Ag}_{2} \mathrm{O} @ \mathrm{NZU}$ and (F) $\mathrm{Ag}^{0} @ \mathrm{NZU}$.

\subsection{Transmission Electron Microscopy (TEM)}

Figure 8 shows the TEM images of the samples on which the presence of nanoparticles is clear. $\mathrm{Fe}_{3} \mathrm{O}_{4}$ NPs size ranged in 5-50 nm, while the $\mathrm{Ag}_{2} \mathrm{O}$ NPs size was below $5 \mathrm{~nm}$ and the $\mathrm{Ag}^{0} \mathrm{NPs}$ size was between $15-20 \mathrm{~nm}$. With the exception of $\mathrm{Ag}_{2} \mathrm{O}$ these values are in general agreement with the NPs size calculations based on XRD data.

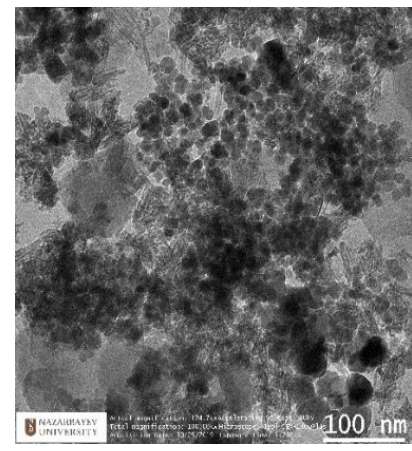

(A)

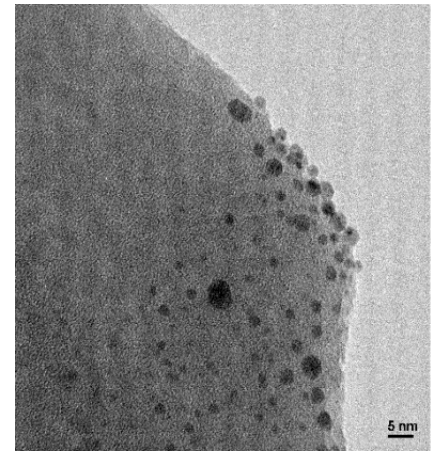

(B)

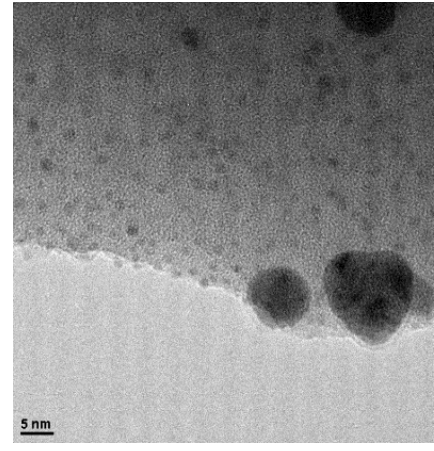

(C)

Figure 8. Transmission electron microscopy images of (A) $\mathrm{Fe}_{3} \mathrm{O}_{4} @ N Z U,(B) \mathrm{Ag}_{2} \mathrm{O} @ N Z U$ and (C) $\mathrm{Ag}^{0} @ \mathrm{NZU}$.

\subsection{Catalytic Discoloration of $M B$}

Figure 9 shows the discoloration of $\mathrm{MB}$ with $\mathrm{H}_{2} \mathrm{O}_{2}$ over the surfaces of the samples after $24 \mathrm{~h}$. It is obvious that the $\mathrm{Fe}_{3} \mathrm{O}_{4} @ \mathrm{NZU}$ exhibited the best performance in comparison to other samples. Also, NZU-Na removes almost $42 \%$ of MB owing to its adsorption properties and Fe content allowing Fenton or Fenton-like reactions to occur (see XPS results). Given this level of removal by NZU-Na, it is obvious that $\mathrm{Ag}_{2} \mathrm{O} @ \mathrm{NZU}$ and $\mathrm{Ag}^{0} @ \mathrm{NZU}$ showed very low activity. The $\mathrm{Ag}^{0}$ sample performance is considerably lower that this found by Colar et al. who used $\mathrm{Ag}^{0}$ supported on clinoptilolite reaching $84 \%$ removal [36]. However, this can be explained as the main difference is that in the paper mentioned 
photocatalysis was employed and also different experimental conditions e.g., different solid mass to liquid volume ratio and $\mathrm{pH}$.

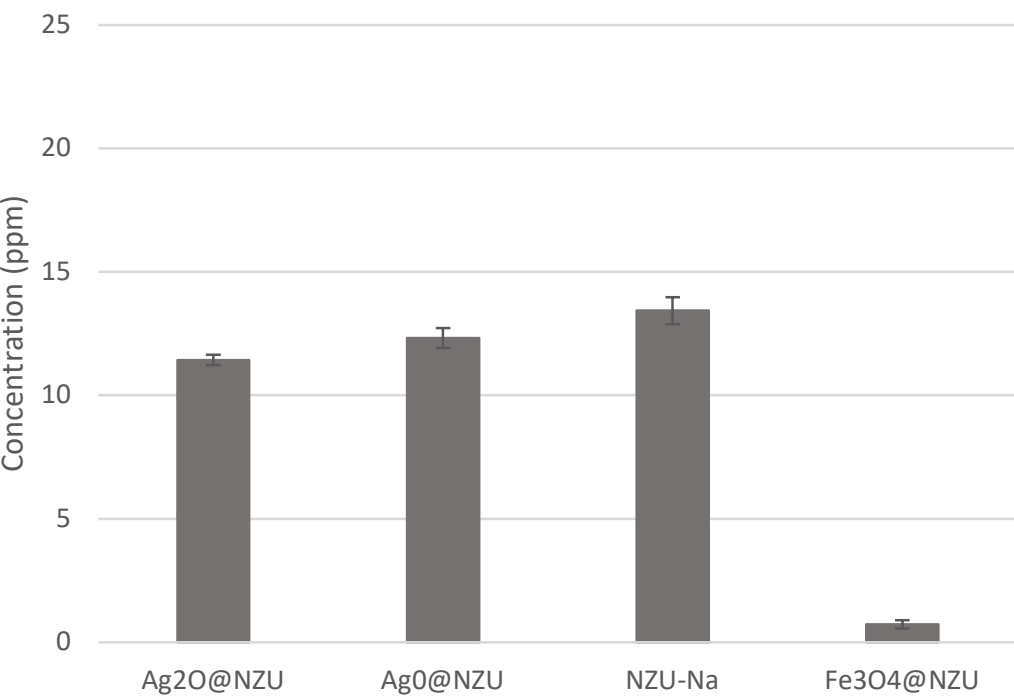

Figure 9. Discoloration of $\mathrm{MB}$ solutions by the modified zeolites $\left(\mathrm{H}_{2} \mathrm{O}_{2}\right.$ concentration: $\left.42.4 \mathrm{mM}\right)$.

Further experiments were carried out under the same experimental conditions by using only NZU-Na and $\mathrm{Fe}_{3} \mathrm{O}_{4} @ \mathrm{NZU}$ samples with the addition of total carbon (TC) measurements (Figure 10). Although TC measurements do not provide information on the formed degradation intermediates, it is a simple and efficient way to study the mineralization of MB [33]. The complete oxidation of MB is represented by the following reaction [25]:

$$
\mathrm{C}_{16} \mathrm{H}_{18} \mathrm{~N}_{3} \mathrm{SCl}+52 \mathrm{H}_{2} \mathrm{O}_{2} \rightarrow 16 \mathrm{CO}_{2}+0.5 \mathrm{O}_{2}+58 \mathrm{H}_{2} \mathrm{O}+3 \mathrm{HNO}_{3}+\mathrm{H}_{2} \mathrm{SO}_{4}+\mathrm{HCl}
$$

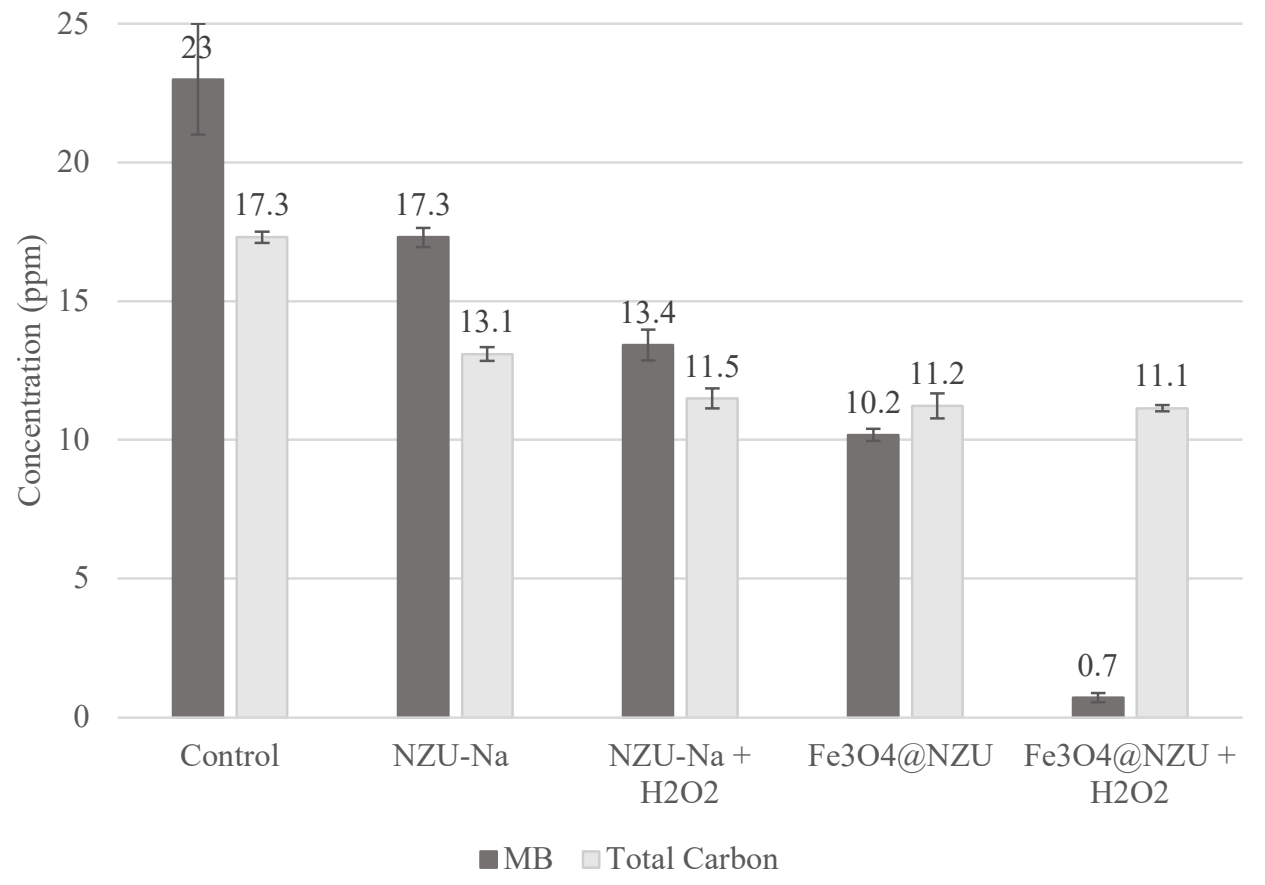

Figure 10. Discoloration of $\mathrm{MB}$ solutions and and TC removal by the modified zeolites $\left(\mathrm{H}_{2} \mathrm{O}_{2}\right.$ concentration: $42.4 \mathrm{mM})$. 
The results obtained show that without the addition of $\mathrm{H}_{2} \mathrm{O}_{2}$ the NZU-Na removed $25 \%$ of $\mathrm{MB}$ and the $\mathrm{Fe}_{3} \mathrm{O}_{4} @ \mathrm{NZU}$ sample $55 \%$, which upon the addition of $\mathrm{H}_{2} \mathrm{O}_{2}$ was increased to $42 \%$ and $97 \%$, respectively. The TC removal was between $25-36 \%$ for all samples, with or without $\mathrm{H}_{2} \mathrm{O}_{2}$, which is mainly attributed to adsorption, and thus the mineralization of $\mathrm{MB}$ to $\mathrm{CO}_{2}$ is either absent or not significant. A proposed degradation and mineralization $\mathrm{MB}$ mechanism has been provided elsewhere [35]. During the oxidation $\mathrm{Cl}-$ is first ionized and then several bonds in the $\mathrm{MB}$ molecule brake under the effect of radicals; first $\mathrm{N}-\mathrm{CH}_{3}$ oxidized into $\mathrm{HCHO}$ or $\mathrm{HCOOH}$, followed by the $\mathrm{C}-\mathrm{S}$ and $\mathrm{C}-\mathrm{N}$ which produce molecules like phenyl thiophene, 4-aminobenzenesulfonic acid and $p$-dihydroxybenzene. The final products are inorganic ions, such as $\mathrm{CO}_{2}, \mathrm{H}_{2} \mathrm{O}, \mathrm{Cl}^{-}, \mathrm{SO}_{4}{ }^{2-}$ and $\mathrm{NO}_{3}{ }^{-\prime \prime}$. The maximum MB removal achieved is comparable to other zeolite-based catalysts presented in Table 1.

These results show that $\mathrm{MB}$ adsorption is the main mechanism for the TC removal. The ability of natural zeolites to adsorb MB is well documented [36,46]. Briefly, MB upon dissolution releases cations into the solution, which are attracted by the permanent negative lattice charge of the zeolites. Also, the temporary surface charge of natural zeolites is governed by the solution $\mathrm{pH}$ and becomes more negative as $\mathrm{pH}$ is increasing contributing to the adsorption of cations [47]. However, we postulate that the pore size could hinder the adsorption by excluding large molecules from the zeolite structure.

The iron of the parent zeolite contributed to the oxidation of MB. Specifically, iron is well known to catalyze the decomposition of hydrogen peroxide into hydroxyl radicals that are powerful oxidants for organic compounds. This reaction is known as the Fenton reaction. The Fenton reaction is among the most widely applied advanced oxidation processes, in which the Fenton's reagent, a mixture of a ferrous salt (catalyst) and hydrogen peroxide (oxidant), is used to destroy refractory organic compounds [48,49]. The Fenton reaction depends on the production of hydroxyl radicals and it is considered as a convenient and economical process [50]. The mechanism is described by the following reactions when no organic compounds are present in the solution [51]:

$$
\begin{gathered}
\mathrm{Fe}^{2+}+\mathrm{H}_{2} \mathrm{O}_{2} \rightarrow \mathrm{Fe}^{3+}+\mathrm{OH}^{\bullet}+\mathrm{OH}^{-} \\
\mathrm{Fe}^{3+}+\mathrm{H}_{2} \mathrm{O}_{2} \rightarrow \mathrm{Fe}^{2+}+\mathrm{HO}_{2}^{\bullet}+\mathrm{H}^{+} \\
\mathrm{OH}^{\bullet}+\mathrm{H}_{2} \mathrm{O}_{2} \rightarrow \mathrm{HO}_{2}^{\bullet}+\mathrm{H}_{2} \mathrm{O} \\
\mathrm{OH}^{\bullet}+\mathrm{Fe}^{2+} \rightarrow \mathrm{Fe}^{3+}+\mathrm{OH}^{-} \\
\mathrm{Fe}^{3+}+\mathrm{HO}_{2}^{\bullet} \rightarrow \mathrm{Fe}^{2+}+\mathrm{O}_{2} \mathrm{H}^{+} \\
\mathrm{Fe}^{2+}+\mathrm{HO}_{2}^{\bullet}+\mathrm{H}^{+} \rightarrow \mathrm{Fe}^{3+}+\mathrm{H}_{2} \mathrm{O}_{2} \\
2 \mathrm{HO}_{2}^{\bullet} \rightarrow \mathrm{H}_{2} \mathrm{O}_{2}+\mathrm{O}_{2}
\end{gathered}
$$

Equation (2) occurs in acidic conditions. The chemical Equation (3) between ferric ions $\left(\mathrm{Fe}^{3+}\right)$ and $\mathrm{H}_{2} \mathrm{O}_{2}$ is known as a Fenton-like reaction. When $\mathrm{Fe}^{2+}$ is initially present all reactions above take place, while for Fe(III) Reaction (3) is the first step. Hydroxyl radicals attack organic molecules according to the following reaction:

$$
\mathrm{RH}+\mathrm{OH}^{\bullet} \rightarrow \mathrm{H}_{2} \mathrm{O}+\mathrm{R}^{\bullet} \rightarrow \text { further oxidation }
$$

As is clear from the results, the magnetite greatly enhanced the oxidation of $\mathrm{MB}$ and oxidizes part of $\mathrm{MB}$ even in the absence of $\mathrm{H}_{2} \mathrm{O}_{2}$. This is a result of higher content of $\mathrm{Fe}^{3+}$ in the zeolite (see Table 2).

In Figure 11 the kinetics of discoloration for the first $150 \mathrm{~min}$ are presented. It is clear that in the presence of $\mathrm{H}_{2} \mathrm{O}_{2} \mathrm{Fe}_{3} \mathrm{O}_{4} @ N Z U$ sample resulted in fast discoloration of $\mathrm{MB}$, while the higher $\mathrm{H}_{2} \mathrm{O}_{2}$ concentration greatly enhances the kinetics. Although the differences between Na-NZU with and without $\mathrm{H}_{2} \mathrm{O}_{2}$ and the $\mathrm{Fe}_{3} \mathrm{O}_{4} @ \mathrm{NZU}$ without $\mathrm{H}_{2} \mathrm{O}_{2}$ after 24 h, they show the same removal up to $150 \mathrm{~min}$ supporting the hypothesis of adsorption as the predominant mechanism of removal at the initial stages followed immediately by oxidation. 


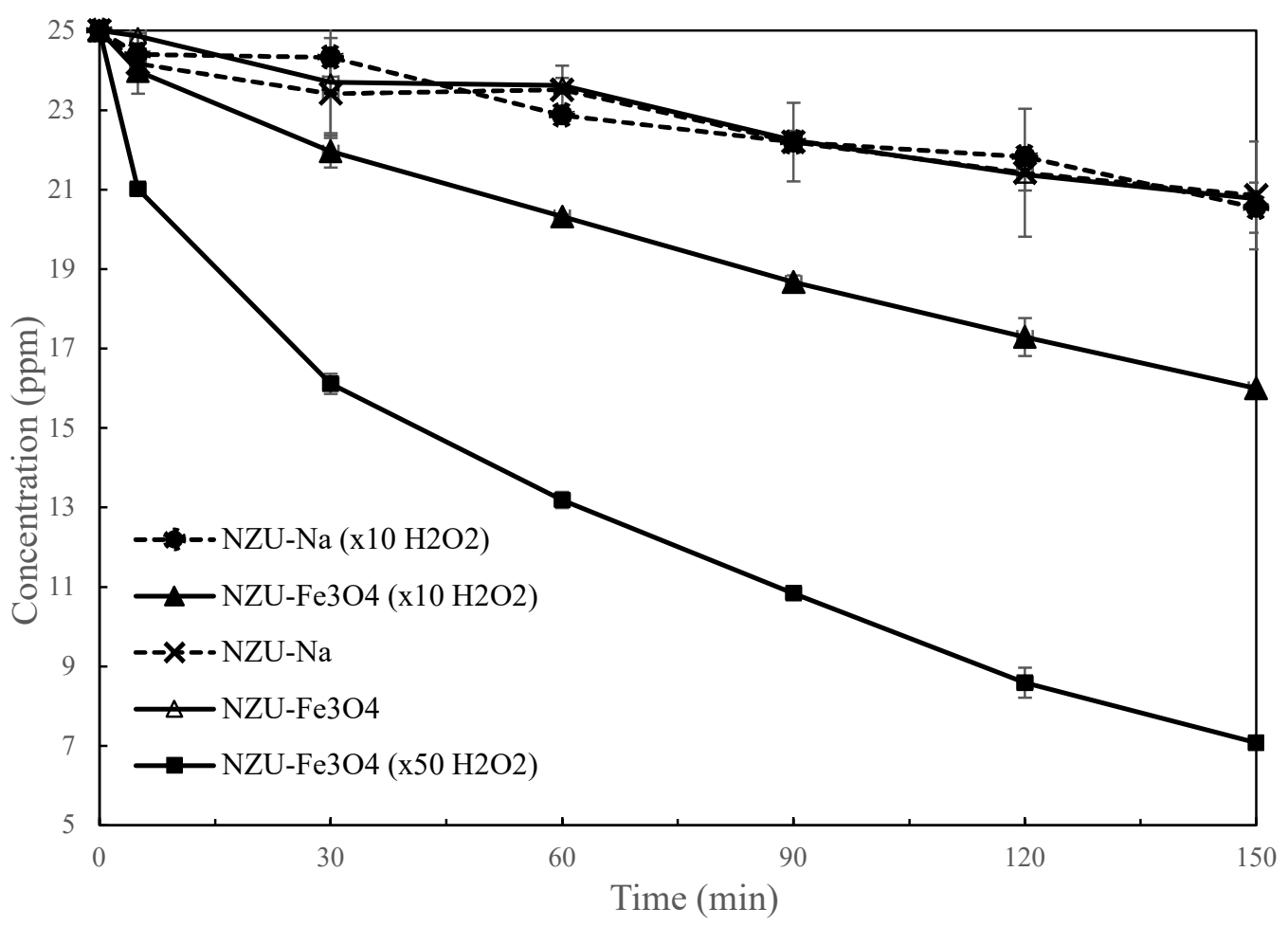

Figure 11. Kinetics of MB solutions discoloration by the modified zeolites.

Reaction rate models were applied on $\mathrm{Fe}_{3} \mathrm{O}_{4} @ \mathrm{NZU}$ experimental data and the results are shown in Figure 12 and Table 3. The models used are the following:

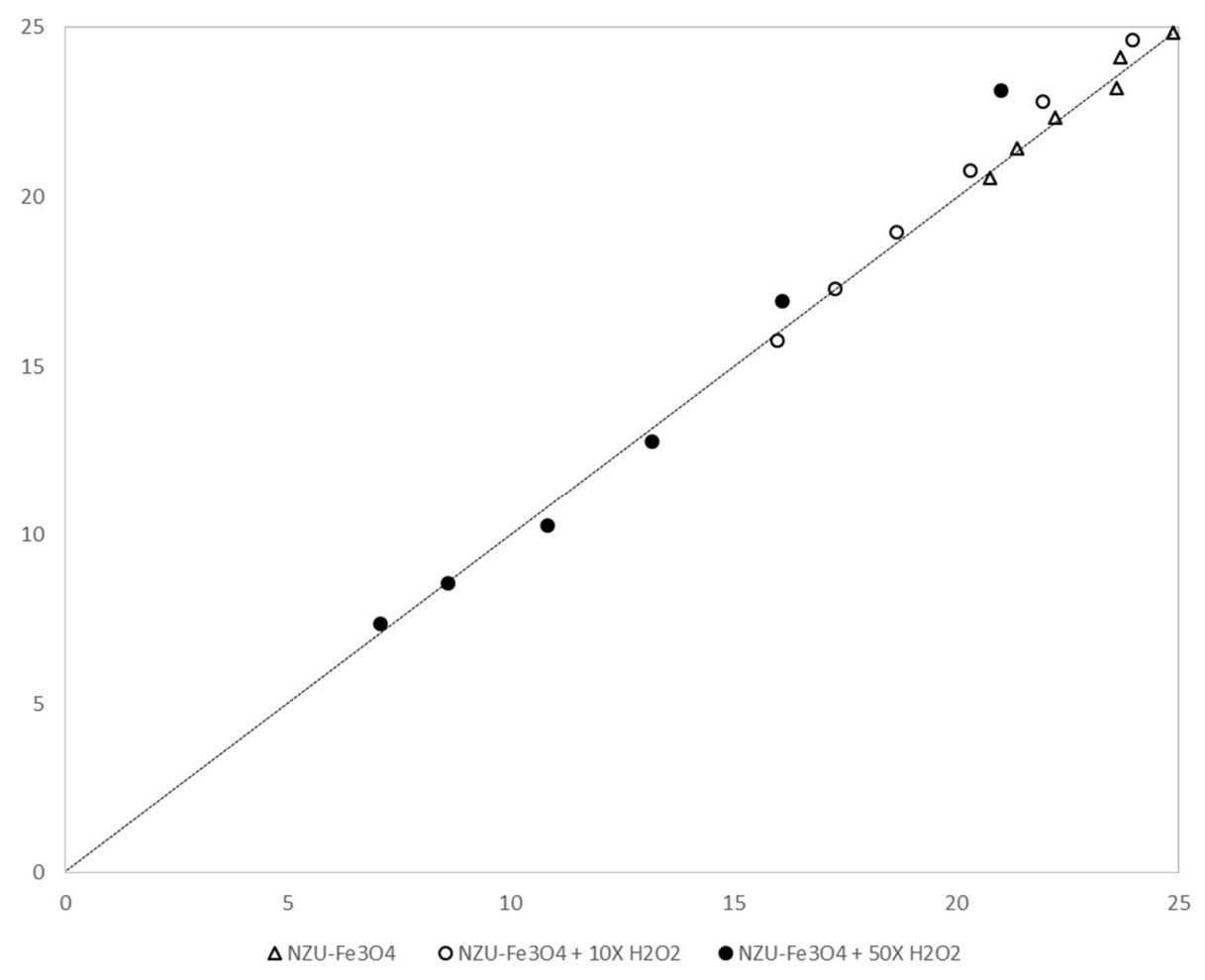

Figure 12. Models results. 
Table 3. Models results.

\begin{tabular}{cccc}
\hline $\mathbf{H}_{\mathbf{2}} \mathbf{O}_{\mathbf{2}} \mathbf{( M m )}$ & $\mathbf{k}\left(\mathbf{m i n}^{-\mathbf{1}}\right)$ & Reaction Order & Average Absolute Error $\mathbf{( \% )}$ \\
\hline 0 & 0.0293 & 0 & 0.8 \\
42.4 & 0.00307 & 1 & 1.7 \\
212 & 0.00064 & 2 & 2.8 \\
\hline
\end{tabular}

Zero order:

$$
\mathrm{C}_{\mathrm{t}}=\mathrm{C}_{\mathrm{o}}-\mathrm{k} \cdot \mathrm{t}
$$

First order:

$$
\mathrm{C}_{\mathrm{t}}=\mathrm{C}_{\mathrm{o}} \cdot \exp (-\mathrm{k} \cdot \mathrm{t})
$$

Second order:

$$
\frac{1}{\mathrm{C}_{\mathrm{t}}}=\frac{1}{\mathrm{C}_{\mathrm{o}}}+\mathrm{k} \cdot \mathrm{t}
$$

where $C_{o}$ and $C_{t}$ the initial and at time $(t)$ concentration and $(k)$ the reaction rate constant. The average absolute error shows that the application of the model is satisfactory. The overall reaction is of zero order in the absence of $\mathrm{H}_{2} \mathrm{O}_{2}$, first order for low concentration of $\mathrm{H}_{2} \mathrm{O}_{2}$ and second order for high $\mathrm{H}_{2} \mathrm{O}_{2}$ concentration, an indication that the reaction path depends on the oxidant $\left[\mathrm{H}_{2} \mathrm{O}_{2}\right]$ concentration. It has been reported that the products distribution is strongly related to the initial molar ratio of $\mathrm{H}_{2} \mathrm{O}_{2}$ /organic compound [52,53]. As a result, different initial concentrations of oxidant, namely of $\mathrm{H}_{2} \mathrm{O}_{2}$, can lead to different reaction pathways and products. The opposite trend was observed by Jakab et al. [33] who used a $\mathrm{Cu}^{2+}$ exchanged natural zeolite, however UV was combined with $\mathrm{H}_{2} \mathrm{O}_{2}$ and thus the oxidation conditions were different. Zhang et al. [40] observed no influence of the $\mathrm{H}_{2} \mathrm{O}_{2}$ on the reaction order but they used an organic form of $\mathrm{Fe}^{2+}$ and thus the reaction system is different. Finally, literature review shows that the $\mathrm{H}_{2} \mathrm{O}_{2}$ oxidation reaction is of first order in most studies (Table 1).

\section{Conclusions}

Natural zeolite-based silver and magnetite nanocomposites were successfully synthesized and tested in the catalytic oxidation of methylene blue in water. The zeolite was impregnated with approximately $5.5 \mathrm{wt} \%$ of Fe in the form of magnetite nanoparticles of size of $32 \mathrm{~nm}$ and $6.4 \mathrm{wt} \%$ $\mathrm{Ag}$ in the form of silver oxide and metallic silver nanoparticles of sizes of 42 and $20 \mathrm{~nm}$, respectively. The results show that $\mathrm{MB}$ adsorption contributes significantly to the total removal, the iron of the parent zeolite contributes to the oxidation of $\mathrm{MB}$, the magnetite oxidizes part of $\mathrm{MB}$ even in the absence of $\mathrm{H}_{2} \mathrm{O}_{2}$ and the addition of magnetite greatly enhances the oxidation of MB. The oxidation of MB is partial without evidence of mineralization. The application of reaction rate models on the experimental data where $\mathrm{H}_{2} \mathrm{O}_{2}$ was used was satisfactory with an average absolute error between $0.8-2.8 \%$. In the absence of $\mathrm{H}_{2} \mathrm{O}_{2}$ the reaction for Na-NZU and $\mathrm{Fe}_{3} \mathrm{O}_{4} @ \mathrm{NZU}$ is of zeroth order confirming that adsorption is the main mechanism at the initial stages followed by oxidation in later stages. The reaction order for $\mathrm{Fe}_{3} \mathrm{O}_{4} @ \mathrm{NZU}$ swifts from zero, to first and second order depending on the $\mathrm{H}_{2} \mathrm{O}_{2}$ concentration, an indication that the reaction path changes.

Author Contributions: Conceptualization, V.J.I.; Methodology, V.J.I.; Software, J.C.B.; Validation, V.J.I., S.P. and J.C.B.; Formal Analysis, V.J.I. and S.P.; Investigation, A.K., N.K. and K.M.; Resources, V.J.I.; Data Curation, V.J.I.; Writing-Original Draft Preparation, V.J.I.; Writing—Review \& Editing, V.J.I. and S.P.; Visualization, V.J.I.; Supervision, V.J.I.; Project Administration, V.J.I.; Funding Acquisition, V.J.I. and J.C.B. All authors have read and agreed to the published version of the manuscript.

Funding: This research was funded Nazarbayev University, Grant Number 110119FD4536 and Kingston University c/o GCRF Grant Number P2034-106. The APC was funded by Nazarbayev University.

Acknowledgments: The authors would like to thank the University of Alicante for the XPS analysis.

Conflicts of Interest: The authors declare no conflict of interest. 


\section{References}

1. Métivier-Pignon, H.; Faur-Brasquet, C.; le Cloirec, P. Adsorption of dyes onto activated carbon cloths: Approach of adsorption mechanisms and coupling of ACC with ultrafiltration to treat coloured wastewaters. Sep. Purif. Technol. 2003, 31, 3-11. [CrossRef]

2. Rafatullah, M.; Sulaiman, O.; Hashim, R.; Ahmad, A. Adsorption of methylene blue on low-cost adsorbents: A review. J. Hazard. Mater. 2010, 177, 70-80. [CrossRef] [PubMed]

3. Sheng, J.; Xie, Y.; Zhou, Y. Adsorption of methylene blue from aqueous solution on pyrophyllite. Appl. Clay Sci. 2009, 46, 422-424. [CrossRef]

4. Li, Y.; Du, Q.; Liu, T.; Peng, X.; Wang, J.; Sun, J.; Wang, Y.; Wu, S.; Wang, Z.; Xia, Y.; et al. Comparative study of methylene blue dye adsorption onto activated carbon, graphene oxide, and carbon nanotubes. Chem. Eng. Res. Des. 2013, 91, 361-368. [CrossRef]

5. Ravikumar, K.; Deebika, B.; Balu, K. Decolourization of aqueous dye solutions by a novel adsorbent: Application of statistical designs and surface plots for the optimization and regression analysis. J. Hazard. Mater. 2005, 122, 75-83. [CrossRef]

6. McMullan, G.; Meehan, C.; Conneely, A.; Kirby, N.; Robinson, T.; Nigam, P.; Banat, I.M.; Marchant, R.; Smyth, W.F. Microbial decolourisation and degradation of textile dyes. Appl. Microbiol. Biotechnol. 2001, 56, 81-87. [CrossRef]

7. Pearce, C.I.; Lloyd, J.R.; Guthrie, J.T. The removal of colour from textile wastewater using whole bacterial cells: A review. Dye. Pigment. 2003, 58, 179-196. [CrossRef]

8. Lee, J.W.; Choi, S.P.; Thiruvenkatachari, R.; Shim, W.G.; Moon, H. Evaluation of the performance of adsorption and coagulation processes for the maximum removal of reactive dyes. Dye. Pigment. 2006, 69, 196-203. [CrossRef]

9. Robinson, T.; McMullan, G.; Marchant, R.; Nigam, P. Remediation of dyes in textile effluent: A critical review on current treatment technologies with a proposed alternative. Bioresour. Technol. 2001, 77, 247-255. [CrossRef]

10. Banat, I.M.; Nigam, P.; Singh, D.; Marchant, R. Microbial decolorization of textile-dye-containing effluents: A review. Bioresour. Technol. 1996, 58, 217-227. [CrossRef]

11. IARC. Chemical and physical data. Pharm. Drugs 2000, 1981, 100-104.

12. Perry anc Meinhard, P.M.E. Necrotic subcutaneous abscesses following injections of methylene blue. Br. J. Clin. Pract. 1974, 28, 289-291.

13. Ruhlen, J.L. Tissue necrosis. Cutaneous and subcutaneous damage following extravasation of methylene blue. J. Kans. Med. Soc. 1982, 83, 236-260. [PubMed]

14. Sharr, M.M.; Weller, R.O.; Brice, J.G. Spinal cord necrosis after intrathecal injection of methylene blue. J. Neurol. Neurosurg. Psychiatry 1978, 41,384-386. [CrossRef]

15. Troche, B.I. The Methylene Blue Baby. N. Engl. J. Med. 1989, 320, 1756-1757. [CrossRef]

16. Spahr, R.C.; Salsburey, D.J.; Krissberg, A.; Prin, W. Intraamniotic injection of methylene blue leading to methemoglobinemia in one of twins. Int. J. Gynecol. Obstet. 1980, 17, 477-478. [CrossRef]

17. Vincer, M.J.; Allen, A.C.; Evans, J.R.; Nwaesei, C.; Stinson, D.A. Methylene-blue-induced hemolytic anemia in a neonate. Can. Med. Assoc. J. 1987, 136, 503-504.

18. Serota, F.; Bernbaum, J.; Schwartz, E. The methylene-blue baby. Lancet 1979, 314, 1142-1143. [CrossRef]

19. Cowett, R.M.; Hakanson, D.O.; Kocon, R.W.; Oh, W. Untoward neonatal effect of intraamniotic administration of methylene blue. Obstet. Gynecol. 1976, 48, 74S-75S.

20. McEnerney, J.K.; McEnerney, L.N. Unfavorable neonatal outcome after intraamniotic injection of methylene blue. Obstet. Gynecol. 1983, 61, 35S-37S.

21. Coddington, C.C.; Anderson, T.L.; Accetta, C.R.; Swanson, J.; Kruger, T.; Hodgen, G.D. Adverse effects of methylene blue on human sperm motility, components of human reproductive tract fluids, and mouse embryo cleavage. Fertil. Steril. 1989, 51, 480-485. [CrossRef]

22. Turner, J. Book review. J. Transp. Geogr. 2013, 106. [CrossRef]

23. Brownstein, S.; Liszauer, A.D.; Jackson, W.B. Ocular complications of a topical methylene blue-vasoconstrictor-anesthetic preparation. Can. J. Ophthalmol. 1989, 24, 317-324. [PubMed]

24. Salem, I.A.; El-Maazawi, M.S. Kinetics and mechanism of color removal of methylene blue with hydrogen peroxide catalyzed by some supported alumina surfaces. Chemosphere 2000, 41, 1173-1180. [CrossRef] 
25. Wu, Y.; Yang, M.; Hu, S.; Wang, L.; Yao, H. Characteristics and mechanisms of 4A zeolite supported nanoparticulate zero-valent iron as Fenton-like catalyst to degrade methylene blue. Toxicol. Environ. Chem. 2014, 96, 227-242. [CrossRef]

26. Simoncic, P.; Armbruster, T. Cationic methylene blue incorporated into zeolite mordenite-Na: A single crystal X-ray study. Microporous Mesoporous Mater. 2005, 81, 87-95. [CrossRef]

27. Smith, J.V. Definition of a zeolite. Zeolites 1984, 4, 309-310. [CrossRef]

28. Liebau, F. Zeolites and clathrasils-Two distinct classes of framework silicates. Zeolites 1983, 3, $191-193$. [CrossRef]

29. Sartbaeva, A.; Wells, S.A.; Treacy, M.M.J.; Thorpe, M.F. The flexibility window in zeolites. Nat. Mater. 2006, 5, 962-965. [CrossRef]

30. Groen, J.C.; Peffer, L.A.A.; Moulijn, J.A.; Pérez-Ramírez, J. On the introduction of intracrystalline mesoporosity in zeolites upon desilication in alkaline medium. Microporous Mesoporous Mater. 2004, 69, 29-34. [CrossRef]

31. Roland, E. Hindustrial Production of Zeolites. Stud. Surf. Sci. Catal. 1989, 46, 645-659. [CrossRef]

32. Lopes, J.H.; Nogueira, F.G.; Gonçalves, M.; Oliveira, L.C. Modified Zeolite with Transition Metals Cu and Fe for Removal of Methylene Blue from Aqueous Medium: Mass Spectrometry Study. Bull. Chem. React. Eng. Catal. 2015, 10, 237-248. [CrossRef]

33. Jakab, Á.; Colar, L.A.; Pode, R.; Cocheci, L.; Manea, F. Catalytic photodegradation and mineralization of cationic dye methylene blue from aqueous solution onto copper doped zeolite. Rev. Chim. 2012, 63, 1016-1022.

34. Wardhani, S.; Rahman, M.F.F.; Purwonugroho, D.; Tjahjanto, R.T.; Damayanti, C.A.; Wulandari, I.O. Photocatalytic Degradation of Methylene Blue Using TiO2-Natural Zeolite as A Photocatalyst. J. Pure Appl. Chem. Res. 2016, 5, 19-27. [CrossRef]

35. Karimi-Shamsabadi, M.; Nezamzadeh-Ejhieh, A. Comparative study on the increased photoactivity of coupled and supported manganese-silver oxides onto a natural zeolite nano-particles. J. Mol. Catal. A Chem. 2016, 418-419, 103-114. [CrossRef]

36. Colar, L.A.; Jakab, A.; Manea, F.; Pode, R.; Orha, C. Photocatalytic performance of Ag-modified natural zeolite catalyst for photocatalysis degradation of Methylene Blue (MB) under VIS irradiation. WIT Trans. Ecol. Environ. 2012, 164, 335-344. [CrossRef]

37. SRajabi, K.; Sohrabnezhad, S. Synthesis and characterization of magnetic core with two shells: Mordenite zeolite and $\mathrm{CuO}$ to form Fe3O4@MOR@CuO core-shell: As a visible light driven photocatalyst. Microporous Mesoporous Mater. 2017, 242, 136-143. [CrossRef]

38. Tedla, H.; Díaz, I.; Kebede, T.; Taddesse, A.M. Synthesis, characterization and photocatalytic activity of zeolite supported $\mathrm{ZnO} / \mathrm{Fe} 2 \mathrm{O} 3 / \mathrm{MnO} 2$ nanocomposites. J. Environ. Chem. Eng. 2015, 3, 1586-1591. [CrossRef]

39. Zhang, Y.; Shang, J.; Song, Y.; Rong, C.; Wang, Y.; Huang, W.; Yu, K. Selective Fenton-like oxidation of methylene blue on modified Fe-zeolites prepared via molecular imprinting technique. Water Sci. Technol. 2017, 75, 659-669. [CrossRef]

40. Zhang, J.; Hu, F.T.; Liu, Q.Q.; Zhao, X.; Liu, S.Q. Application of heterogenous catalyst of tris $(1,10)$-phenanthroline iron(II) loaded on zeolite for the photo-Fenton degradation of methylene blue. React. Kinet. Mech. Catal. 2011, 103, 299-310. [CrossRef]

41. Subramanian, E.; Subbulekshmi, N.L. Enhanced heterogeneous wet hydrogen peroxide catalytic oxidation performance of fly ash-derived zeolite by CuO incorporation. Sci. Iran. 2017, 24, 1189-1202. [CrossRef]

42. Nassar, M.Y.; Abdelrahman, E.A. Hydrothermal tuning of the morphology and crystallite size of zeolite nanostructures for simultaneous adsorption and photocatalytic degradation of methylene blue dye. J. Mol. Liq. 2017, 242, 364-374. [CrossRef]

43. Wojtaszek-Gurdak, A.; Zielinska, M.; Ziolek, M. MWW layered zeolites modified with niobium species-Surface and catalytic properties. Catal. Today 2019, 325, 89-97. [CrossRef]

44. Stylianou, M.; Inglezakis, V.; Agapiou, A.; Itskos, G.; Jetybayeva, A.; Loizidou, M. A comparative study on phyllosilicate and tectosillicate mineral structural properties. Desalin. Water Treat. 2018, 112, 119-146. [CrossRef]

45. Allen, G.C.; Curtis, M.T.; Hooper, A.J.; Tucker, P.M. X-ray photoelectron spectroscopy of iron-oxygen systems. J. Chem. Soc. Dalt. Trans. Dalt. Trans. 1974, 1525-1530. [CrossRef]

46. Wang, S.; Zhu, Z.H. Characterisation and environmental application of an Australian natural zeolite for basic dye removal from aqueous solution. J. Hazard. Mater. 2006, 136, 946-952. [CrossRef] 
47. Wang, X.; Nguyen, A.V. Characterisation of electrokinetic properties of clinoptilolite before and after activation by sulphuric acid for treating CSG water. Microporous Mesoporous Mater. 2016, 220, 175-182. [CrossRef]

48. Andreozzi, R.; Caprio, V.; Insola, A.; Marotta, R. Advanced oxidation processes (AOP) for water purification and recovery. Catal. Today. 1999, 53, 51-59. [CrossRef]

49. Tarr, M.A. Chemical Degradation Methods for Wastes and Pollutants: Environmental and Industrial Applications; CRC Press: Boca Raton, FL, USA, 2003.

50. Pignatello, J.J.; Oliveros, E.; MacKay, A. Advanced oxidation processes for organic contaminant destruction based on the fenton reaction and related chemistry. Crit. Rev. Environ. Sci. Technol. 2006, 36, 1-84. [CrossRef]

51. Jain, B.; Singh, A.K.; Kim, H.; Lichtfouse, E.; Sharma, V.K. Treatment of organic pollutants by homogeneous and heterogeneous Fenton reaction processes. Environ. Chem. Lett. 2018, 16, 947-967. [CrossRef]

52. Lipczynska-Kochany, E.; Bolton, J.R. Flash photolysis/HPLC applications. 2. Direct photolysis vs. hydrogen peroxide mediated photodegradation of 4-chlorophenol as studied by a flash photolysis/HPLC technique. Environ. Sci. Technol. 1992, 26, 259-262. [CrossRef]

53. Poulopoulos, S.G.; Arvanitakis, F.; Philippopoulos, C.J. Photochemical treatment of phenol aqueous solutions using ultraviolet radiation and hydrogen peroxide. J. Hazard. Mater. 2006, 129, 64-68. [CrossRef] [PubMed]

(C) 2020 by the authors. Licensee MDPI, Basel, Switzerland. This article is an open access article distributed under the terms and conditions of the Creative Commons Attribution (CC BY) license (http://creativecommons.org/licenses/by/4.0/). 